\title{
Structural Control of Sugar Chains in Animal Cells
}

\author{
動物細胞における糖鎖構造制御
}

\author{
Fukuta, Kazuhiro ; Asanagi, Mineko ; and Makino, Tadashi \\ Life Science Laboratory, Mitsui Chemicals, Inc., 1144 Togo, Mobara, Chiba 297-0017, Japan \\ FAX: 81-475-25-6553, E-mail: kazuhiro.fukuta@mitsui-chem.co.jp
}

Key Words : animal cell, sugar chain, glycosyltransferase, interferon- $\gamma$, immunoglobulin $M$

\begin{abstract}
Sugar chains are synthesized in cells by sequential reactions of glycosylation enzymes. These sugar chains do not have uniform structure, but rather constitute a mixture of various structures which correspond to the intermediates of maturation. Sugar chains on recombinant glycoproteins produced by animal cells also contain various forms. A method of producing uniform glycoproteins with specific sugar chain structure is required. We have been studying biosynthetic control of sugar chains on glycoproteins using animal cells. In the present review, we present the results of our research, focusing on the following two subjects: remodeling branch structures of complex-type sugar chains on interferon- $\gamma$ (IFN- $\gamma$ ); control of addition of bisecting GlcNAc to immunoglobulin $\mathrm{M}(\operatorname{IgM})$. In the investigation into sugar chains on IFN- $\gamma$, we used Chinese hamster ovary cells as hosts for recombinant production of IFN- $\gamma$, and overexpressed genes for $\mathrm{N}$-acetylglucosaminyltransferases IV and V, thereby changing sugar chains on IFN- $\gamma$ to highly branched types. In the investigation into sugar chains on IgM, we controlled addition of bisecting GlcNAc to sugar chains on IgM by regulating intracellular activity of $\beta 1,4$-galactosyltransferase and $N$-acetylglucosaminyltransferase III. Our results show that regulation of the expression of glycosylation enzymes can be effectively used to control sugar chain structures.
\end{abstract}

\section{A. Introduction}

Sugar chains are initially added to proteins in the endoplasmic reticulum (ER), and subsequently they are modified in the ER and Golgi complex (through processing by enzymes involved in sugar chain biosynthesis) until they achieve maturity (Fig. 1). Such processing of sugar chains is catalyzed by enzymes such as glycosidases and glycosyltransferases, which are distributed in the ER and Golgi complex according to the order of the glycosylation pathway. The reactions catalyzed by these enzymes do not occur to an equal degree to all the glycoprotein molecules; thus, the extent of branching or elongation of sugar chains differs among glycoproteins from molecule to molecule. Thus, in contrast to DNA and proteins (which are biosynthesized according to a template), sugar chains are synthesized in step-
要 約

細胞内における糖鎖の生合成は、糖鎖生合成酵素群による 逐次反応であることから、生成物である糖鎖の構造は一様でな く、糖鎖成熟途上の色々な段階のものを含む混合物となる。動 物細胞を宿主としてつくった組換え糖タンパク質の糖鎖もやは り不均一で、特定の糖鎖構造を有する糖タンパク質を均一性高 くつくる技術の確立が望まれる。このため、我々は動物細胞を 用いて糖タンパク質の糖鎖構造を制御することに取り組んで来 た。ここでは、インターフェロン- $\gamma(\mathrm{IFN}-\gamma)$ を用いて複合型糖鎖 の分岐構造を改変した例と、イムノグロブリン $\mathrm{M}(\mathrm{IgM})$ を用いて バイセクティングGlcNAcの付加を制御した例を中心に我々の研 究を紹介する。IFN - $\gamma$ をモデルとした研究では、宿主細胞とし てチャイニーズハムスター卵巣細胞を用い、 $N$-アセチルグルコ サミン転移酵素IVおよびVの遺伝子を高発現させることによっ て、IFN- $\gamma$ の糖鎖を多分岐化させることができた。IgMを用いた 研究では、B 細胞内の $\beta 1,4-$-ガラクトース転移酵素と $N$-アセチル グルコサミン転移酵素IIIの活性バランスを調節することによ り、IgMの糖鎖に対するバイセクティングGlcNAcの付加を制御 できた。糖鎖生合成酵素群の発現制御により、糖鎖構造をかな り有効に制御できるようである。

\section{A.はじめに}

糖鎖は細胞内の小胞体で付加され、さらに引き続き小胞体 およびゴルジ体のなかで糖鎖生合成酵素群により修飾を受けて 成熟する(図1)。このような糖鎖修飾は、小胞体からゴルジ体に かけて順々に分布する各種のグリコシダーゼや糖転移酵素など の糖鎖生合成酵素群の間を糖タンパク質が通過する間に各酵素 の反応によって行われる。この一連の反応は、糖タンパク質分 子すべてに均一には働かないので、糖鎖の分岐度や糖鎖末端ま での伸長度は各々の分子でまちまちとなる。このように糖鎖の 生合成は、鋳型を用いるDNAやタンパク質の場合とは異なり、 糖鎖生合成酵素群による逐次反応によって行われることから、 


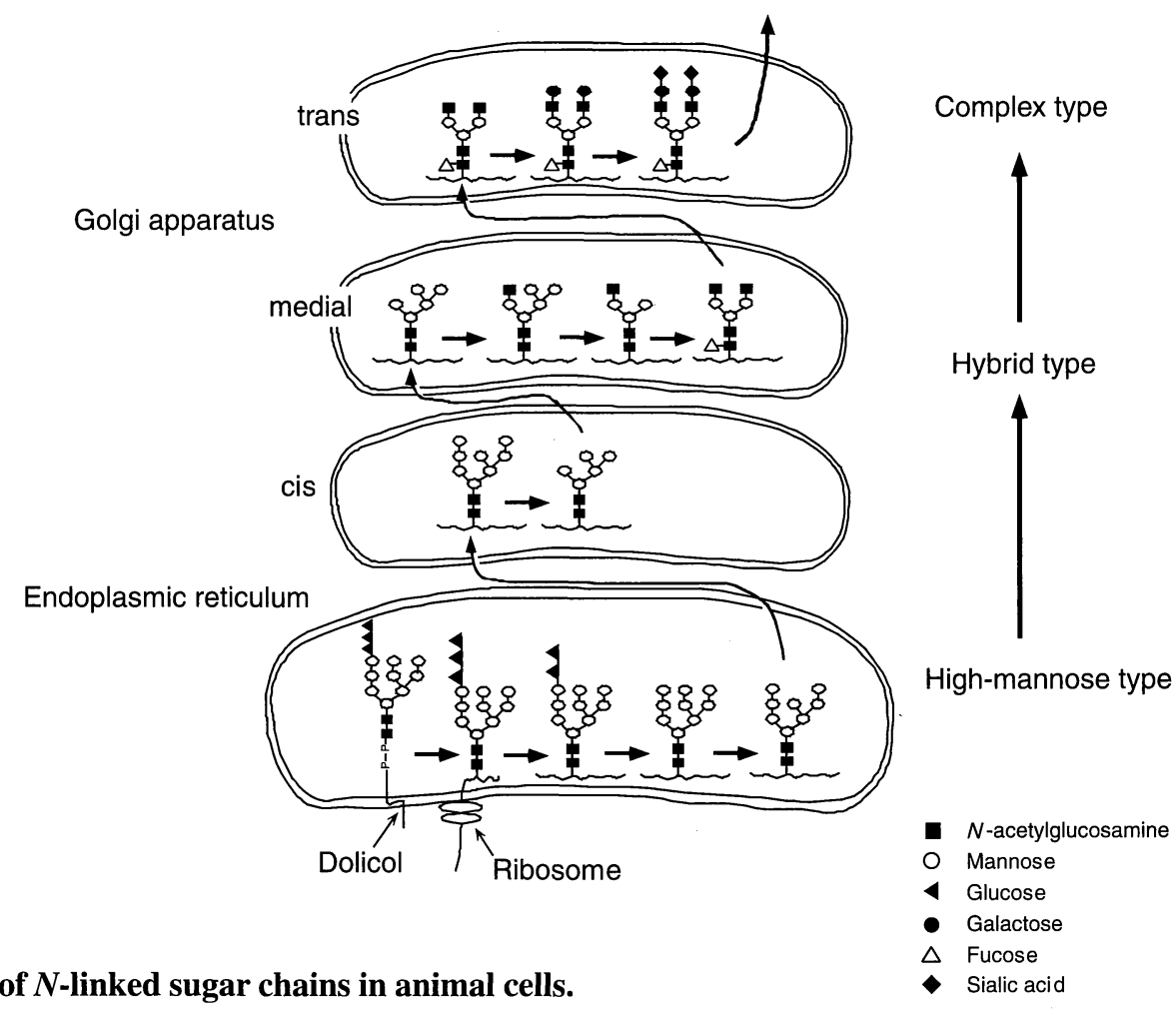

Fig. 1. Biosynthesis of $N$-linked sugar chains in animal cells.

by-step reactions catalyzed by glycosylation enzymes. Hence, sugar chains do not have a uniform structure, but rather have various structures which correspond to the intermediates of the maturation process.

Animal cells are the main cell type used for recombinant production of glycoproteins. Sugar chains on glycoproteins produced by animal cells also contain various forms. More than ten different sugar chain structures have been observed for a single glycoprotein. The glycosylation profiles of glycoproteins produced by mammalian cells other than human cells resemble the profiles of human glycoproteins rather than those of lower species (for example, yeasts, plants, and insects). However, sugar chains produced by mammalian cells other than human cells often have structures that are not observed in human glycoproteins, and they are immunogenic in the human body $(1,2)$. Overcoming this impediment to the use of animal cells is an important issue in the development of pharmaceuticals. Furthermore, when we intend to study and use glycoproteins with sugar chains of specific structures (glycoforms), it is required to establish a method that selectively produce specific glycoforms. Currently available information regarding the relationship between the structure of a sugar chain and its biological activity is inadequate. However, in the case of erythropoietin (an erythropoietic factor), for example, a highly branched glycoform is known to show high activity in vivo(3).

We conducted research into production of glycoproteins using mammalian cells, with the aim of uniformly producing specific glycoforms. Specifically, we attempted to control the
生成物である糖鎖の構造は一様でなく、糖鎖成熟途上の色々な 段階のものを含む混合物となる。

糖タンパク質の組換え生産においては、宿主として主に動 物細胞が用いられているが、動物細胞の作る糖タンパク質糖鎖 もやはり不均一で、同じ一つのタンパク質に付加する糖鎖から 十数種以上の糖鎖型が見いだされる。ヒト以外の動物細胞の生 産する糖タンパク質の糖鎖パターンは、系統の離れた生物種 (例 えば酵母、植物、昆虫)に比べればヒトの糖鎖パターンに近いと いえるが、実際にはヒト糖タンパク質の糖鎖に見られない構造 も出現し、また中にはヒトに対して抗原性を示す糖鎖構造もあ る $(1,2)$ 。したがって、医薬品開発を考える場合、動物細胞にお けるこのような不具合を改善することは重要な課題である。ま た、特定の糖鎖構造を有する糖タンパク質(glycoform)の有用性を 検証し、その応用を考えるためには、特定の glycoformを選択的 に生産する技術が必要となる。糖鎖型と糖タンパク質の生理活性 との関係についての情報は充分ではないが、赤血球増殖因子であ るエリスロポエチンの場合では、分岐の多い糖鎖型を有する glycoformにおいてin vivo 活性が高いことが知られている(3)。

以上のことから、我々は動物細胞を用いて糖タンパク質を 生産するにあたり、多様な glycoform の中から特定のglycoform を均一性高くつくることを目指して研究を進めてきた。この目 的のために、我々は生体内に扔ける細胞表面認識のためのシグ 
Trends in Glycoscience and Glycotechnology Vol.13 No.72 (July 2001) pp.395-405

biosynthesis of asparagine-linked ( $N$-linked) sugar chains that are thought to play important roles as signals for cell-surface recognition in the body.

\section{B. Strategy for Structural Control of $N$-linked Sugar Chains}

In $N$-glycosylation, a block of oligosacharides (which serves as a precursor) is initially synthesized on the dolichol in the ER. This whole oligosaccharide block is then transferred en bloc to the Asn residue of a protein which has been imported into the ER. While proteins to which sugar chains are added in this manner move through the ER and Golgi complex toward secretion, the sugar chains are brought to maturity through various modifications. Along the way, these sugar chains, which are initially high-mannose-types, are eventually converted to complex types via hybrid types. Thus, complex-type sugar chains are the most mature among $N$-linked sugar chains, and structural control of complex-type sugar chains is important.

A glycosylation profile is considered to reflect, to some extent, the expression profile of enzymes (located in the ER and Golgi complex) that are involved in glycosylation. Actually, even for a single glycoprotein, glycosylation profiles vary, depending on the organs producing the glycoprotein. Speciesspecific glycosylation profiles are also observed $(4,5)$. Also, glycosylation profiles can vary among glycoproteins produced by a single cell. In the case of a glycoprotein that contains multiple sugar chains, the structures of sugar chains sometimes differ among glycosylation sites (6-8). Thus, there are two major factors in the structural regulation of sugar chains added to proteins: glycosylation machinery in cells, and the backbone structure of a protein. These factors suggest two strategies for control and remodeling of sugar chains. One is to modify the glycosylation machinery in cells, and the other is to change the sequence of amino acids of the protein of interest. The former strategy is considered more practical than the latter, because it preserves the function of the glycoprotein and avoids immunogenicity. Therefore, we attempted to control intracellular activities of glycosyltransferases, by regulating the expression of these enzymes in cells using genetic engineering.

The cloning of genes for glycosyltransferases is critical for such a procedure. However, at the beginning of the 1990s, when we started our research, only a small number of glycosyltransferase genes had been cloned. Therefore, despite the availability of genetic technology, remodeling sugar chains was difficult. However, during the decade that followed, there were great advances in cDNA cloning of glycosyltrnasferases $(9,10)$. Current situation makes possible the introduction of glycosyltransferase genes into cells. Our research was thus greatly aided by recent advances in cDNA cloning of glycosyltransferses.
ナル分子としての機能が重要視されるアスパラギン結合型 $(N$-結 合型)糖鎖の生合成を制御することに取り組んだ。

\section{B. $N$-結合型糖鎖の構造制御戦略}

$N$-結合型糖鎖の生合成では、まず小胞体で糖鎖前駆体とな るオリゴ糖ブロックがドリコール上に合成され、小胞体に送り 込まれたタンパク質のAsn残基に、前もって合成されたこのオリ ゴ糖ブロックがブロックごと転移される。このようにして糖鎖 付与を受けたタンパク質が小胞体からゴルジ体を通って分泌さ れるまでの間に、糖鎖は様々な修飾を受けて成熟型へと成長す る。この過程で糖鎖は最初、高マンノース型と呼ばれる構造を とっているが、途中、ハイブリッド型と呼ばれる構造を経て、 最後に複合型と呼ばれる構造に至る。すなわち、複合型糖鎖は 最も成熟した型の糖鎖であり、複合型糖鎖の構造を制御するこ とが $N$-結合型糖鎖の構造制御において重要と考えられる。

糖鎖パターンは小胞体・ゴルジ体に分布している糖鎖生合 成酵素群の発現状態をある程度反映している。実際、同種の夕 ンパク質であっても、付加される糖鎖のパターンは、そのタン パク質を生産する臟器によって異なることが知られており、動 物種による差異も見られる $(4,5)$ 。しかし、同一の細胞が生産す るタンパク質では必ず同一の糖鎖パターンを示すということで もない。一つのタンパク質に複数の糖鎖が付加されている場合 でも、糖鎖の結合位置によって構造が異なることもある(6-8)。 このように、タンパク質に付加される糖鎖の構造に影響を与え る因子としては、宿主細胞内にある糖鎖生合成機構に関わる因 子と、糖鎖が付加されるタンパク質の構造に関わる因子の 2 種類 が挙げられる。従って、糖鎖構造を制御したり改変したりする ためには、宿主細胞の糖鎖生合成機構に手を加えるか、また は、目的のタンパク質のアミノ酸配列を変更するか、という2つ の方法が考えられる。しかし、タンパク質の機能を維持するこ とや、抗原性の問題を考慮した場合、前者の方法がより実際的 と考えられる。そこで我々は、宿主細胞の糖転移酵素群の発現 量を遺伝子工学的手法により調節し、各酵素の活性バランスを 制御する研究に取り組んだ。

ところが、このためには糖転移酵素群の遺伝子クローニン グが必須である。我々が研究を開始した1990年初頭は、限られ た種類の糖転移酵素でしか遺伝子クローニングが成功していな かったため、遺伝子工学的手法をもってしても糖鎖を改変する ことは容易ならざる状況であった。しかし、その後今日に至る 10年の間に糖転移酵素遺伝子のクローニングが爆発的に進んた $(9,10)$ ことから、現在では、多種類の糖転移酵素の遺伝子を細胞 に導入することが可能となっており、このことは、我々の研究 を進展させる上で強力な追い風となった。 


\section{Relationship between the Expression of Glycosyltrans-} ferases in a Host Cell and Sugar Chain Structure

When we started our research into controlling expression of glycosyltransferases, the number of cloned genes encoding glycosyltransferases was limited. To overcome this problem, we attempted to modify glycosylation machinery in cells using cell fusion. In this procedure, we established a hybridoma, 3-4, by fusing human B cell line No.12 [which produces immunoglobulin M (IgM) against Pseudomonas aerginosa] with human myeloma P109 (11). We compared the sugar chain structures of IgM molecules produced by parental No.12 cells with those produced by hybridoma 3-4 cells (12). The $\mu$-chain of IgM contains five $N$-glycosylation sites; we analyzed sugar chain structures at each site. Sugar chains at sites Asn171, Asn 332 and Asn395 were complex-type, and those at Asn 402 and Asn563 were high-mannose-type, as reported previously $(7,8)$. In comparing IgM molecules produced by parent cells and hybridoma cells, differences were observed among complex-type structures. These differences were related to the percentage of sugar chains containing bisecting GlcNAc (Fig. 2). In the case of IgM derived from parental cells, the percentages of sugar chains containing bisecting GlcNAc were $49.9 \%$ at Asn171, $67.8 \%$ at Asn332, and $81.3 \%$ at Asn395. In the case of IgM from hybridoma, the respective percentages were $3.7 \%, 8.7 \%$ and $15.3 \%$; significantly less than the values for parental cells. Activity of GnT-III (which adds bisecting GlcNAc to $N$-glycans) in hybridomas was found to be less than $1 / 10$ of that observed in parental No.12 cells. This decrease was due to the lack of GnT-III in P109, the human myeloma that was the other parent of the hybridoma. The decreased GnT-III activity in the hybridoma was reflected in the decrease in addition of bisecting GlcNAc. We also measured $\beta 1,4$-galactosyl-transferase $(\beta 1,4-G a l T)$ activity in each cell line. The hybridoma showed activity intermediate between that of parent cells (No.12<3-4 $<$ P109). $\beta 1,4-$ GalT activity in the hybridoma was 1.8 -fold higher than in No.12 cells, although the activity of $\beta 1,4-G a l T$ in No.12 cells was sufficient for complete galactosylation. The results of this experiment showed that we can modify glycosylation machinery using cell fusion, and that the expression of glycosyltransferases in cells is reflected in the structures of sugar chains on glycoproteins they produce.

\section{C. 宿主細胞の糖転移酵素発現量と糖鎖構造の関係}

糖転移酵素遺伝子の発現制御に関する研究を進めるにあた り、初期の研究段階では、利用できる糖転移酵素遺伝子の種類 が限られていたという問題があった。そこで、当初、我々は細 胞融合を利用し、細胞の糖鎖生合成機構を改変することに取り 組んだ。この実験では、抗緑膿菌IgM抗体を生産するヒトB細胞 (No.12株)にヒトミエローマ(P109株)を融合してハイブリドーマ (3-4株)を取得した(11)。親細胞であるNo.12株とハイブリドーマ 3-4株の生産するIgMにおいて、糖鎖構造を比較した(12)。IgMの $\mu$ 鎖には $N$-結合型糖鎖の付加部位が5 所存在するが、本実験で は、これらの部位別に糖鎖構造を解析した。その結果、従来知 られているように $(7,8) 、 \operatorname{IgM} の \mu$ 鎖における5 所の糖鎖付加部 位のうち、Asn171, Asn332, Asn395に付加されているものは複合 型、Asn402, Asn563に付加されているものは高マンノース型で あった。親細胞のIgMとハイブリドーマのIgMとの比較では、複 合型糖鎖の構造に差異が見られた。この差異は、バイセクティ ングGlcNAc(図2)と呼ばれる構造を持つ糖鎖の存在比率に起因し た。親細胞ではバイセクティングGlcNAcを持つ糖鎖の割合が Asn171, Asn332, Asn395においてそれぞれ 49.9\%、67.8\%、81.3\% であったが、ハイブリドーマにおいては、それぞれ3.7\%、 8.7\%、15.3\%と大きく低下していた。バイセクティングGlcNAc は、 $N$-アセチルグルコサミン転移酵素III (GnT-III) の作用によっ て糖鎖に付与されるが、ハイブリドーマの GnT-III活性は、親細 胞No.12株に比べて1/10以下に低下していた。このことは、細胞 融合におけるもう一方の親細胞として用いたヒトミエローマ P109 がGnT-III活性を有していないことによるものであるが、こ のようにして低下したGnT-III活性を反映して、ハイブリドーマ ではバイセクティングGlcNAcの付加が減少したことが確認でき た。また、各細胞の $\beta 1,4$-ガラクトース転移酵素( $\beta 1,4-G a l T) の$ 活性についても測定したところ、ハイブリドーマは、両親細胞 の中間 $($ No.12 $<3-4<$ P109) の活性を示し、No.12株に比べると約 1.8倍に増加していた。ただし、IgMの糖鎖にガラクトースを付加 するという点では、No.12株の $\beta 1,4$-GalT活性で充分であった。 この実験において、細胞融合によって糖鎖生合成機構を改变でき ることが示されたとともに、細胞の糖転移酵素発現量が、生産す る糖タンパク質の構造に反映されることも確認できた。

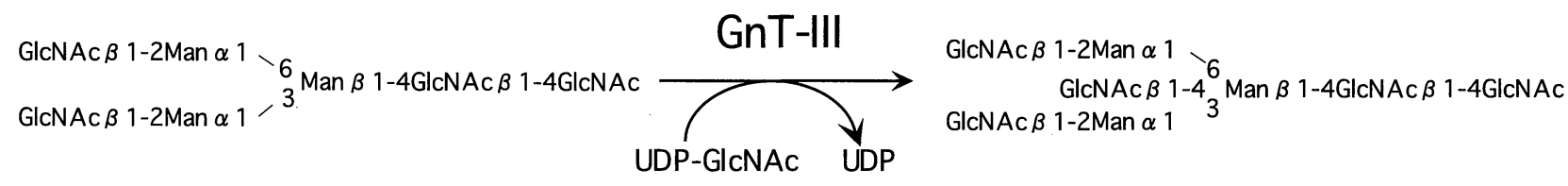

Fig. 2. Reaction of GnT-III.

$\beta 1,4$-linked GlcNAc attached to $\beta 1$,4-Man in the trimannosyl core is termed bisecting GlcNAc. 


\section{Remodeling of Sugar Chains into Highly Branched Struc- tures}

In complex-type sugar chains, branches are constructed by addition of GlcNAcs by various $N$-acetylglucosaminyltransferases (GnTs)(Fig. 3), and this forms the skeleton of the sugar chain. In the complex-type sugar chains in mammals, including humans, branch structures with a maximum of four antennae are observed (Fig. 4). In complex-type sugar chains, the branch structures form a skeleton on which the side chains are elongated. The enzymes responsible for the formation of tri- and tetra-antennary structures are GnT-IV and GnT-V. The above-

\section{D．複合型糖鎖の高分岐化による改変}

複合型糖鎖の骨格は、各種のN-アセチルグルコサミン転移 酵素 $(\mathrm{GnT})$ によって付与されるGlcNAcによって形成される分岐 構造(図3)で成り立っている。ヒトを含む哺乳類の複合型糖鎖で は、4分岐型までの分岐構造が知られている(図4)。複合型糖鎖で は、この分岐構造が糖鎖の基本骨格となり、この骨格の先に側 鎖が形成される。3分岐型や 4分岐型の糖鎖形成に必須な $\mathrm{GnT}$ 醅 素はGnT-IVとGnT-Vである。GnTによって付加されるGlcNAcで も、上述のGnT-IIIによって付加されるバイセクティングGlcNAc に関しては、その先に側鎖が形成されることがない。そのため

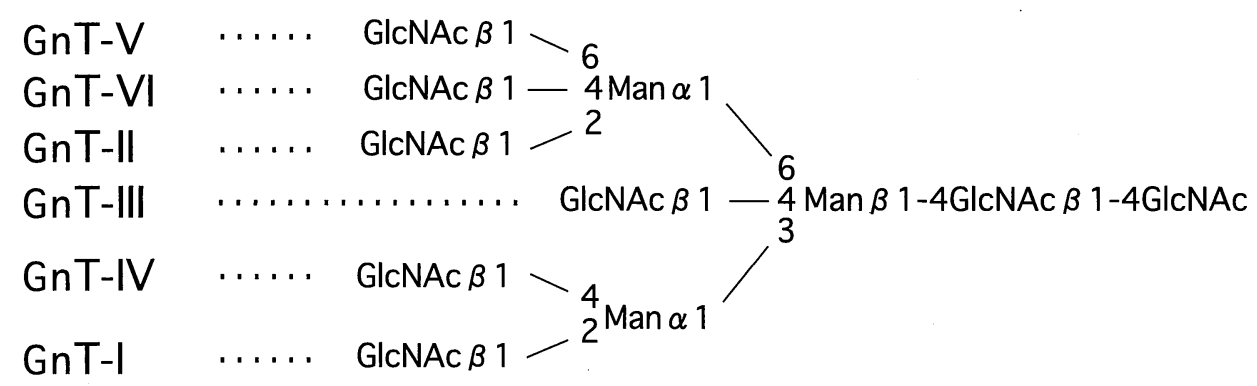

Fig. 3. Classification of GnTs.

GIcNAc $\beta$ 1-2Man $\alpha 1$

GlcNAc $\beta 14$

GICNAC $\beta$ 1-2Man $\alpha 1$

GIcNAc $\beta 1-2$ Man $\alpha 1$ ${ }_{3}^{6}$ Man $\beta$ 1-4GIcNAc $\beta$ 1-4GIcNAc

GIcNAc $\beta 1-2 \operatorname{Man} \alpha 1$

Biantennary

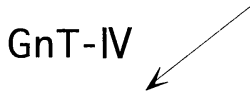

${ }_{3}^{6} \operatorname{Man} \beta 1-4 \mathrm{GlcNAc} \beta$ 1-4GIcNAc

Triantennary

( $\beta 1,4$-branched)

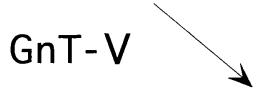

GlcNAc $\beta 1$. GIcNAc $\beta$ 1-2Man $\alpha$ 1 $\operatorname{GlcNAc} \beta 1$ - 4 ${ }_{3}^{6} \operatorname{Man} \beta 1-4$ GlcNAc $\beta$ 1-4GIcNAc GIcNAc $\beta$ 1-2Man $\alpha 1$

\section{GnT-V}

GlcNAc $\beta 1$ GIcNAc $\beta$ 1-2Man $\alpha 1$

GICNAc $\beta 1-2 \operatorname{Man} \alpha 1$

${ }_{3}^{6} \operatorname{Man} \beta 1-4 \mathrm{GICNAc} \beta$ 1-4GIcNAc

Triantennary

( $\beta 1,6-$ branched)

\section{Tetraantennary}

Fig. 4. Reactions of GnT-IV and GnT-V. 
described bisecting GlcNAc (which is added by GnT-III) is not considered a branch, because side chains are not formed on it. Even so, bisecting GlcNAc could possibly be considered a small branch. Although GnTs have been known to exist for many years, cDNA cloning and clarification of their sequences were not achieved until the 1990s. The cDNA sequence of GnT-III was reported by Nishikawa et al. in 1992 (13), and the cDNA sequence of GnT-V was reported by Shoreibah et al. in 1993 (14) and Saito et al. in 1994 (15). The cDNA sequence of GnT-IV (the last of the GnTs to be cloned) was reported by Minowa et al. in 1998(16).

With these developments in cDNA cloning of GnTs, we attempted to remodel biantennary sugar chains into highly branched chains using GnT-IV and GnT-V. We used human interferon- $\gamma($ IFN- $\gamma)$ as a model glycoprotein for this experiment. Chinese hamster ovary (CHO) cells, which we used as host cells, are convenient tools for expression of recombinant proteins, because genes introduced into these cells can be amplified by the gene amplification technique using dihydrofolate reductase (DHFR). Consequently, CHO cells are widely used for recombinant production of glycoproteins. In addition, CHO-derived glycoproteins show glycosylation profiles similar to those of human glycoproteins, so $\mathrm{CHO}$ cells are useful in the industrial production of glycoproteins for human therapy.

The human IFN- $\gamma$ we used as a model glycoprotein consists of 143 amino acids, and contains sugar chains at Asn 25 and Asn 97. Sugar chains on natural human IFN- $\gamma$ are of biantennary structure. CHO cells normally express GnT-IV and GnT-V, but their levels of expression are low. Thus, when IFN- $\gamma$ is produced by normal $\mathrm{CHO}$ cells, the sugar chains on the IFN$\gamma$ are mainly biantennary. We introduced cDNAs for GnT-IV and/or GnT-V into CHO cells, and isolated clones which expressed high levels of GnT-IV and/or GnT-V (17). Structural analysis of sugar chains on IFN- $\gamma$ produced by each clone revealed that they had been changed to primarily tri- and tetraantennary structures, depending on the level of intracellular activity of GnT-IV and GnT-V (Table I). About $60 \%$ of all the sugar chains were of the target branch structure. Thus, the branch structures of sugar chains on IFN- $\gamma$ were changed, without significant difficulty, by overexpressing GnT-IV and/or GnT-V. These results might seem unsurprising. However, the branch structure has been believed to depend on the protein backbone, because the number of glycoproteins carrying tri- or tetraantennary sugar chains is small. Our results have overturned such a previous belief. We also analyzed sugar chains on cellular proteins other than IFN- $\gamma$ that were produced by $\mathrm{CHO}$ cells transfected with GnT-IV and/or GnT-V, and most of these sugar chains had been converted to highly branched types. Thus, it was demonstrated that changing the expression of glycosyltransferases in cells mostly results in remodeling of sugar chain structure.
にバイセクティングGlcNAcは複合型糖鎖の分岐としては見なさ れていないが、小さな分岐と考えることもできる。これら $\mathrm{GnT}$ の存在は、かなり以前から知られていたが、遺伝子が単離され 配列が明確になったのは1990年代になってからである。GnTの うち、GnT-IIIの cDNA配列は 1992年に Nishikawaら(13)によって 報告され、GnT-Vの cDNA配列は1993年にShoreibahら(14)および 1994年にSaitoら(15)によって報告された。また、GnT群の中で、 最後までクローニングがなされずに残っていたGnT-IVは、1998 年にMinowaらにより報告された(16)。

こうして各GnTの遺伝子が揃ったことにより、我々はGnTIVおよびGnT-V利用による2分岐型糖鎖の多分岐型への改変に取 り組んだ。この実験ではヒトインターフェロンー $\gamma($ IFN- $\gamma)$ をモ デルとして用いた。細胞宿主として用いたチャイニーズハムス ター卵巣(CHO)細胞は、ジヒドロ葉酸レダクターゼ(DHFR)を用 いた遺伝子増幅系の利用により、ホスト内で目的遺伝子のコ ピー数を増幅できるので、組換え糖タンパク質を発現させるた めの宿主細胞として好適である。また、つくられる糖鎖のパ ターンがヒトのものに近いので、医療用糖タンパク質の生産に も用いられ、産業的にも価值の高い細胞である。

モデルとして用いたヒトIFN- $\gamma$ は143個のアミノ酸残基から 成り、糖鎖は25番目と97番目のアスパラギンに付加される。天 然のヒトIFN- $\gamma$ には 2 分岐型糖鎖が結合している。CHO細胞は もともとGnT-IVや GnT-Vを発現してはいるが、その発現量は低 いことから、通常のCHO細胞でIFN- $\gamma$ を生産しても、糖鎖は主 として2分岐型である。我々は、このCHO細胞にGnT-IVおよび GnT-Vの片方または両方の遺伝子を導入し、それぞれを高い活 性で発現する細胞株を単離した(17)。生産されるIFN- $\gamma$ の糖鎖構 造を調べたところ、それぞれ細胞内のGnT-IVや GnT-Vの活性に 対応して、主要な糖鎖構造は3分岐型や 4分岐型へと変換されて いた(表I)。目的の分岐を持った糖鎖は全糖鎖のほほ $60 \%$ 前後の 割合に達していた。このように、IFN- $\gamma$ をモデルとして用いた 実験では、GnT-IVや GnT-Vの高発現により、比較的容易に糖鎖 の分岐度を改変できた。このことは、一見当然の結果に見え る。しかし、3分岐型や4分岐型の糖鎖を持つ糖タンパク質の種 類が限られていたことから、これまでは糖鎖の分岐度は夕ンパ ク質の種類で決まるという見方が強かった。今回の結果はそれ をくつがえしたことになる。我々は、上記の GnT-IVまたは GnT-Vを導入したCHO細胞において、IFN - $\gamma$ 以外の、細胞全体 の糖鎖を解析してみたが、全般的に糖鎖の分岐度が増加してい ることも確認した。したがって、糖転移酵素の発現状態を変え ることによって、かなりの程度、糖鎖の構造改変が可能である と考えられた。 
Trends in Glycoscience and Glycotechnology Vol.13 No.72 (July 2001) pp.395-405

Table I. $N$-glycan structures of human IFN- $\gamma$ produced by CHO transfectants.

\begin{tabular}{|c|c|c|c|c|c|}
\hline & \multicolumn{5}{|c|}{ Cell line } \\
\hline & \multirow[b]{2}{*}{ Parent } & \multicolumn{4}{|c|}{ Transfectants } \\
\hline & & GnT-IV & $\begin{array}{c}\text { GnT-V } \\
\text { (moderate level) }\end{array}$ & $\begin{array}{c}\text { GnT-V } \\
\text { (high level) }\end{array}$ & $\begin{array}{l}\text { GnT-IV } \\
\text { GnT-V }\end{array}$ \\
\hline & $\%$ & $\%$ & $\%$ & $\%$ & $\%$ \\
\hline Biantennary & 63.8 & 11.0 & 48.4 & 14.2 & 7.6 \\
\hline Triantennary ( $\beta 1,4$-branched) & 2.5 & 66.9 & 0.7 & 1.0 & 9.3 \\
\hline Triantennary ( $\beta 1,6$-branched) & 12.8 & 2.6 & 23.6 & 55.7 & 10.1 \\
\hline Tetraantennary & 1.0 & 12.4 & 3.3 & 8.7 & 56.2 \\
\hline
\end{tabular}

\section{E. Control of Addition of Bisecting GlcNAc by Regulating the Intracellular Activity of Galactosyltransfease}

In addition to remodeling sugar chains, we attempted to control formation of sugar chain structures. For this purpose, we utilized the competitive behavior of glycosyltransferases involved in sugar chain biosynthesis. Sometimes, more than one glycosyltransferase can react with a particular sugar chain structure, and these enzymes compete for sugar chains of this structure. In such a case, the structure a sugar chain is converted to depends on which enzyme reacts with it first. Regulating activity of these competitive glycosyltransferases is an important means of structural control of sugar chains.

Suppression of the formation of Gao1-3Gal (which is known to be a xenoantigen) is an example of the application of competition between glycosyltransferases. Sugar chains containing Gal $\alpha 1-3 \mathrm{Gal}$ are commonly observed in mice and swine, but not in humans. If a glycoprotein containing Gal $\alpha 1-3 \mathrm{Gal}$ were used in human therapy, or if tissues containing Gal $\alpha 1-3 \mathrm{Gal}$ were transplanted to a human body, immunological rejection would occur. To remove this xenoantigen, some attempts are reportedly made to introduce genes for glycosyltransferases which compete with $\alpha 1,3$-galactosyltransferase ( $\alpha 1,3-$ GalT) into mouse and swine cells, with the aim of suppressing the action of $\alpha 1,3$ GalT (which catalyzes formation of the Gal $\alpha 1-3 \mathrm{Gal}$ linkage). As shown in Fig.5, $\alpha 1,3$-GalT competes with $\alpha 1,2$ fucosyltransferase, $\alpha 2,3-/ \alpha 2,6$-sialyltransferase, and GnT-III. When one of these enzymes was overexpressed, formation of Gal $\alpha 1-3 \mathrm{Gal}$ was suppressed (18-23).

In our study, we addressed the effects of galactosylation. When a sugar chain is galactosylated, actions of many glycosyltransferases are inhibited. We examined this effect using the above-described human B cell line, No.12, which produces IgM. We attempted to disrupt the genes for $\beta 1,4-G a l T$ in these cells using a gene targeting technique. We isolated a clone (single knockout clone) in which one of the $\beta 1,4-G a l T$ alleles, on the chromosome 9, was disrupted (24). The level of $\beta 1,4$ GalT activity in the single knockout clone was about half that of
E ．ガラクトース転移酵素の活性調節によるバイセクティング GlcNAc残基の付加制御

我々は、糖鎖の構造改変に加え、さらに、糖鎖構造を制御 することに取り組んだ。細胞内において糖鎖構造を制御してい る因子は多々あると考えられるが、我々は、糖転移酵素どうし の拮抗作用を糖鎖構造制御に利用することを考えた。糖転移酵 素群の中には、同じ構造の糖鎖を共通の基質とするものがあ り、これらの酵素は共通の基質糖鎖に対して競合し、どちらの 酵素が作用するかによって、糖鎖構造は別々の構造へ導かれる ことになる。このような競合性を有する糖転移酵素の活性バラ ンスを制御することも糖鎖構造を制御する上で重要である。

このような糖転移酵素の競合を糖鎖改変に用いた例とし て、移植抗原として知られる Gal 1-3Gal結合の形成を抑制する 試みがある。Gal 1 1-3Gal 結合単位を含む糖鎖は、マウスやブ夕 などで普通に見られるが、人の体内では合成されない。Galo13Gal構造を含む糖タンパク質をヒトに対する薬剤として用いた り、Galo1-3Gal構造を有する組織をヒトに移植すれば、拒絶反 応を惹起することになる。この様な移植抗原を除くため、Gal $\alpha 1-3 \mathrm{Gal}$ 結合をつくる $\alpha 1,3-$-゙ラクトース転移酵素( $(\alpha 1,3-G a l T) の$ 作用を抑制することを目的として、 $\alpha 1,3-G a l T と$ 競合する糖転移 酵素の遺伝子をマウスやブタの細胞に導入することが試みられ ている。図5の様に、 $\alpha 1,3$ - GalTは、基質となる糖鎖に対して、 $\alpha 1,2$-フコース転移酥素、 $\alpha 2,3$-または $\alpha 2,6$-シアル酸転移酵素、 GnT-III 競合しており、これらの競合酵素のどれかを大量に発 現させると、Gal 1 1-3Gal結合の生成は抑制されることが報告さ れている(18-23)。

我々は、糖鎖がガラクトシル化されると他の糖転移酵素の 作用が阻害されるという点に着目した。ここでは、上述の IgM 生産B細胞を用いて実験を行った。我々は、上述のヒトB細胞 No.12株において、ジーンターゲッティングによる $\beta 1,4-G a l T の$ 遺伝子破壊を試みた。その結果、第9染色体上にコードされる一 対の $\beta 1,4-G a l T$ 遺伝子のうち、一方だけを不活化(シングルノッ クアウト)した細胞を得た(24)。得られたシングルノックアウト 


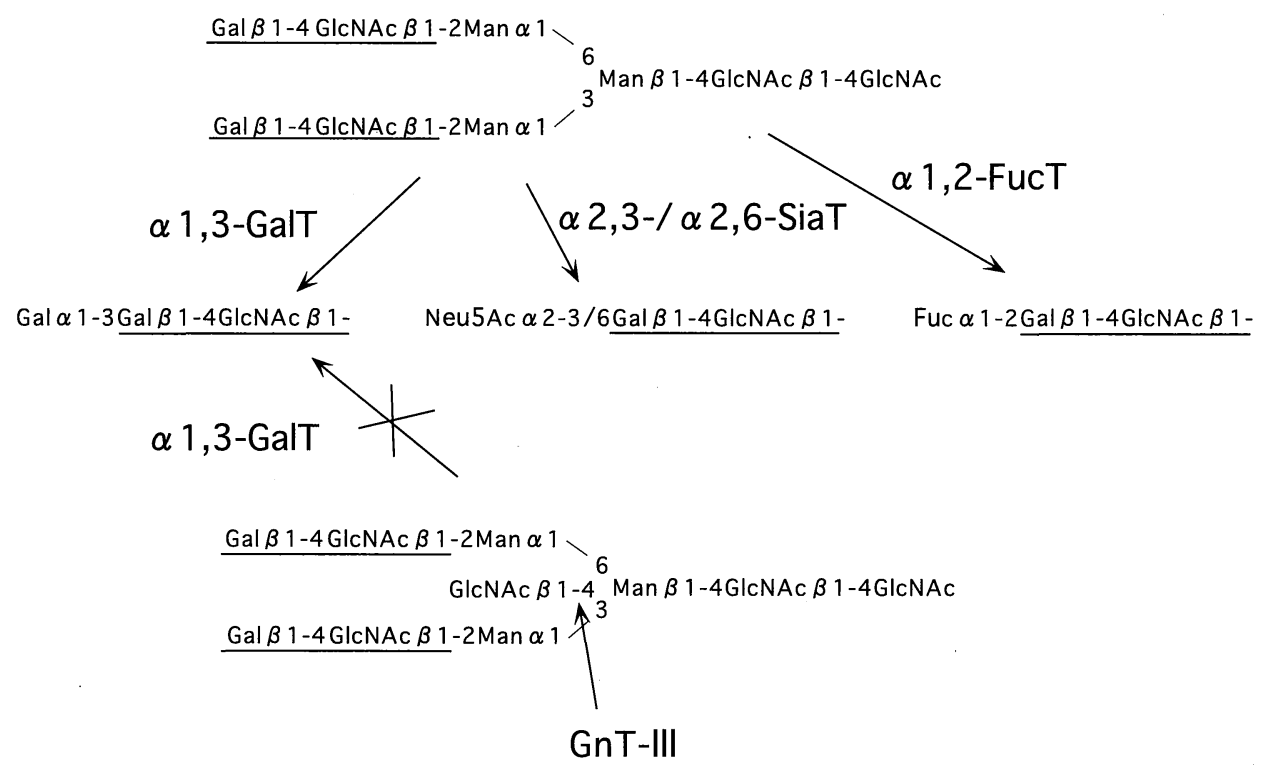

Fig. 5. Glycosyltransferases which compete with $\alpha 1,3-G a l T$.

parent cells, as expected. Structural analysis of sugar chains on the IgM produced by this cell clone showed that the extent of galactosylation was almost complete as seen in the parent cells. This result was interpreted as meaning that $\beta 1,4-G a l T$ activity in the single knockout clone was sufficient for full galactosylation. However, an increase in the percentage of sugar chains containing bisecting GlcNAc was observed in IgM from the single knockout cells. GnT-III (which catalyzes the addition of bisecting GlcNAc) has been observed not to react with galactosylated sugar chains in vitro(25-29)(Fig. 6). Once the acceptor sugar chain is galactosylated, GnT-III does not react with the resultant sugar chain. Thus, GnT-III and $\beta 1,4-G a l T$ compete for the same sugar chains. We consider the above result a reflection of this behavior by enzymes. We also overexpressed $\beta 1,4-G a l T$ in No.12 B cells, and isolated clones expressing different levels of $\beta 1,4-$ GalT. In these clones, addition of bisecting GlcNAc was suppressed inversely at elevated levels of $\beta 1,4-G a l T$ activity. Thus, we demonstrated control of addition of bisecting GlcNAc by regulating the activity of GnT-III and $\beta 1,4-$ GalT, by making use of their competitive behavior.

It has previously been thought that competition between GnT-III and $\beta 1,4-G a l T$ occurs only in vitro. It is known that glycosyltransferases are compartmentalized in Golgi complex in the order in which they act. $\beta 1,4-\mathrm{GalT}$ is localized to the transGolgi and the trans-Golgi network (30-34). GnT-III is thought to be distributed in the medial-Golgi $(35,36)$. Thus, $\beta 1,4-G a l T$ and GnT-III have previously been believed to have different distribution patterns. In contrast, we demonstrated competition between $\beta 1$,4-GalT and GnT-III in cells. Recently, it has been demonstrated that glycosyltransferases are not compartmentalized
株の $\beta 1$,4-GalT活性を測定すると、予想される通り、酵素活性が ほぼ半分に低下していた。この細胞の生産するIgMの糖鎖構造 を解析したところ、ガラクトースの付加率はほぼ100\%に保たれ ており、 $\beta 1,4-G a l T$ 活性は半隇してもガラクトース付加にまだ充 分な量が残存していると解釈できた。一方、この細胞の生産す るIgMの糖鎖においては、バイセクティングGlcNAcを持つ糖鎖 の割合が増加していることが見出された。バイセクティング GlcNAcはGnT-IIIによって付加されるが、GnT-IIIは、ガラクトー ス付加を受けた糖鎖を基質としないことが in vitroの実験におい て知られている(図6)(25-29)。すなわち、ひとたびアクセプター 糖鎖にガラクトース残基が付加されると、このガラクトシル化 された糖鎖に対し、GnT-IIIは反応できない。つまり、GnT-IIIと B1,4-GalTは、同一の糖鎖を基質として競合する。したがって、 上記の現象はこのような酵素の特性が反映されたものと考えら れる。我々は、上記 B細胞 No.12株に $\beta 1,4-G a l T$ 遺伝子を高発現 させる実験も行い、 $\beta 1$ 1, 4-GalT活性の発現の程度が異なる細胞 株を数種単離したが、この場合は、細胞内の $\beta 1,4-G a l T$ 活性の増 加と相反して、バイセクティングGlcNAcの付加が抑制されてい た。このように、細胞内に扔ける両酵素活性の比を調節するこ とにより、GnT-IIIと $\beta 1,4-G a l T$ 競合を利用してバイセクティン グGlcNAcの付加を制御することができた。

しかし、このようなGnT-IIIと $\beta 1,4-G a l T の$ 競合はin vitroで のみ起こるというのが従来の認識である。ゴルジ体内におい て、糖転移酵素は、それらが作用する順に局在していることが

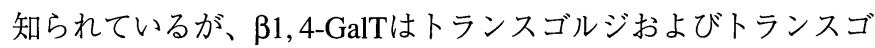
ルジネットワークに存在し(30-34)、GnT-IIIはメディアルゴルジ に存在するとされてきた $(35,36)$ 。すわち、GnT-III と $\beta 1,4-G a l T$ は細胞内の存在場所が異なると考えられてきたのである。これ 

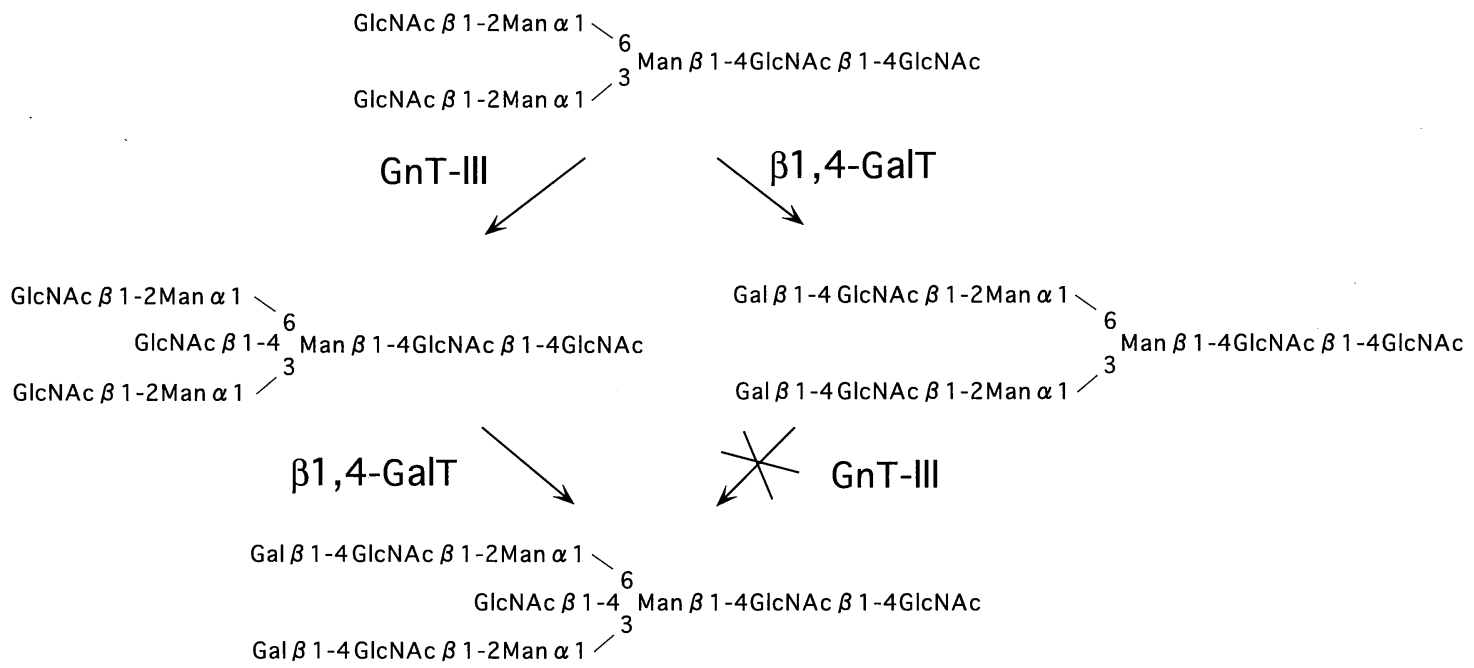

Fig. 6. Reactions of GnT-III and $\beta 1,4-G a l T$.

in a strict manner in the Golgi complex, but are localized in overlapping distributions $(32,33,37)$. $\beta 1,4-G a l T$ and GnT-III will also have overlapping localizations.

Thus, competitive behavior among glycosyltransferases is an important factor (in addition to the individual function of each glycosyltransferase) in controlling sugar chain structure. $\beta 1,4-G a l T$ is known to compete with many glycosyltransferases in vitro, but this behavior has not been examined in vivo. $\beta 1,4-$ GalT may also compete with GnT-IV and GnT-V in cells. We feel that $\beta 1,4-$ GalT should be evaluated as a factor in the regulation of sugar chain processing.

\section{F. Concluding Remarks}

In the present review, we demonstrated that sugar chain structures are controllable, to a significant extent, through regulation of the expression of glycosyltransferases. Sugar chains on glycoproteins now produced industrially are not strictly controlled in detail. Techniques like those described above will be useful for quality control of industrially produced glycoproteins, by reducing heterogeneity of sugar chains. Furthermore, functions of glycoproteins may be improved by using such techniques. The present study was performed according to an engineering approach. However, applying these techniques to glycobiology research will be useful for clarifying the relationship between structure and function of sugar chains.

The following are suggestions for future investigation into detailed control of sugar chains. In addition to transfer of monosaccharides by glycosyltransferases in the Golgi complex, biosynthesis of nucleotide-sugars and transport of these nucleotide-sugars into the Golgi complex are involved in sugar chain biosynthesis. Manipulation of overall biosynthetic machinery involved in attachment of individual monosaccharides to sugar
に対し、実際の細胞内でもGnT-III とß1,4-GalTの競合が起こると いう事実は、我々の研究において明らかにされたものである。 最近、ゴルジ体において、糖転移酵素は厳密に区画されて存在 しているのではなく、ある程度、分布の重なりをもって存在す ることがわかってきた $(32,33,37) 。 \beta 1,4-G a l T$ GnT-IIIも、厳密 に分かれて存在しているのではなく、ある程度分布の重なりが あると推測される。

このように、糖鎖構造を制御する上で、糖転移酵素の単独 の作用以外に、糖転移酵素どうしの拮抗作用も重要なファク ターである。 B1, 4-GalTは、in vitroにおいて多くの他の糖転移酵 素と競合することが知られているが、細胞内での検証は行われ ていない。 1 1,4-GalTは GnT-IVやGnT-V とも細胞内で競合する 可能性があり、糖鎖修飾の制御因子の一つとして $\beta 1,4-G a l T の$ 機 能を評価する必要がありそうである。

\section{F.おわりに}

本稿では糖転移酵素群の発現制御により、糖鎖構造をかな り有効に制御できることを示した。現在のところ、商業的に生 産されている糖タンパク質糖鎖の構造は、必ずしも細部まで制 御されているとは言えず、ここに示したような糖鎖構造を制御 する技術は、糖鎖の不均一性を抑制する意味で工業的な品質管 理に役立つものと考えられる。また、このような技術を利用す ることにより、糖タンパク質の機能を向上させることも期待で きる。ここで述べた研究は、かなりエンジニアリング的なアプ ローチと言えるが、このような手法を糖鎖生物学の領域で用い れば、糖鎖の構造と機能の関係を明らかにすることにも役立つ であろう。

さらに糖鎖構造を精細に制御するための今後の問題として は次のことが言える。元来、糖鎖の生合成には、ゴルジ体内に おける糖転移酵素による単糖の付加だけでなく、基質である糖 クレオチドの合成、ゴルジ内への糖ヌクレオチド輸送なども含 まれている。個々の単糖を糖鎖に結合させるまでの一連の道筋 
chains is necessary for improvement of the level and efficiency of fine control of sugar chain structures.

\section{Acknowledgments}

We thank Dr. Makoto Takeuchi of Kirin Brewery Co.,Ltd. for bovine GnT-IVa cDNA. We would also like to thank the following: Professor Naoyuki Taniguchi, of Osaka University Medical School, for rat GnT-III cDNA; Dr. Michiko.N.Fukuda, of The Burnham Institute, for human $\beta 1,4-G a l T-I$ cDNA.
を全体的に整備する事が、より糖鎖構造制御の精度、効率を向 上させるために必要であろう。

謝 辞

ウシGnT-IVa cDNAを提供していただきましたキリンビール 株式会社の竹内誠博士に厚く御礼申し上げます。また、ラット GnT-III cDNAを提供していただきました大阪大学医学部の谷口 直之教授、ヒト $\beta 1,4-$ GalT-I cDNAを提供していただきましたThe Burnham Instituteの福田道子博士に深く感謝いたします。

\section{References}

1. Galili,U., Macher,B.A., Buehler,J., and Shohet,S.B. (1985) J.Exp.Med. 162, 573-582

2. Noguchi,A., Mukuria,C.J., Suzuki,E., and Naiki,M. (1995) J.Biochem. 117, 59-62

3. Takeuchi,M., Inoue,N., Thomas,W., Strickland,T.W., Kubota,M., Wada,M., Shimizu,R., Hoshi,S., Kozutsumi,H., Takasaki,S., and Kobata,A. (1989) Proc.Natl.Acad.Sci.USA 86, 7819-7822

4. Yamashita,K., Tachibana,Y., Shichi,H., and Kobata,A. (1983) J.Biochem. 93, 135-147

5. Yamashita,K., Hitoi,A., Tateishi,N., Higashi,T., Sakamoto,Y., and Kobata,A. (1983) Arch.Biochem.Biophys. 225, $993-996$

6. Parekh,R.B., Dwek,R.A., Thomas,J.R., Opdenakker,G., Rademacher,T.W., Wittwer,A.J., Howard,S.C., Nelson,R., Siegel,N.R., Jennings,M.G., Harakas,N.K., and Feder,J. (1989) Biochemistry 28, 7644-7662

7. Monica,T.J., Williams,S.B., Goochee,C.F., and Maiorella,B.L. (1995) Glycobiology 5, 175-185

8. Leibiger,H., Kersten,B., Albersheim,P., and, Darvill,A. (1998) Glycobiology 8, 497-507

9. Field,M.C. and Wainwright,L.J. (1995) Glycobiology 5, 463-472

10. Fukuda,M., Bierhuizen,M.F.A., and Nakayama,J. (1996) Glycobiology 6, 683-689

11. O’Oka,H., Chonan,E., Mizutani,K., Fukuda,T., Kuroiwa,Y., Ono,Y. and Shigeta, S. (1992) Microbiol. Immunol. 36, $1305-1316$

12. Fukuta,K., Abe,R., Yokomatsu,T., Kono,N., Nagatomi,Y., Asanagi,M., Shimazaki,Y. and Makino,T. (2000) Arch.Biochem. Biophys. 378, $142-150$

13. Nishikawa,A., Ihara,Y., Hatakeyama,M., Kangawa,K., and Taniguchi,N. (1992) J.Biol.Chem. 267, 18199-18204

14. Shoreibah,M., Perng,G.S., Adler,B., Weinstein,J., Basu,R., Cupples,R., Wen,D., Browne,J.K., Buckhaults,P., Fregien,N., and Pierce,M. (1993) J.Biol.Chem. 268, 15381-15385

15. Saito,H. Nishikawa,A., Gu,J., Ihara,Y., Soejima,H., Wada,Y., Sekiya,C., Niikawa,N., and Taniguchi,N. (1994) Biochem.Biophys.Res.Commun. 198, 318-327

16. Minowa,M.T., Oguri,S., Yoshida,A., Hara,T., Iwamatsu,A., Ikenaga,H., and Takeuchi,M. (1998) J.Biol.Chem. 273, 11556-11562

17. Fukuta,K., Abe,R., Yokomatsu,T., Kono,N., Asanagi,M., Omae,F., Minowa,M.T., Takeuchi,M. and Makino,T. (2000) Glycobiology 10, 421430

18. Sandrin,M.S., Fodor,W.L., Mouhtouris,E., Osman,N., Cohney,S., Rollins,S.A., Guilmette,E.R., Setter,E., Squinto,S.P., and McKenzie,I.F.C. (1995) Nature Med. 1, 1261-1267

19. Sharma,A., Okabe,J., Birch,P., McClellan,S.B., Martin,M.J., Platt,J.L., and Logan,J.S. (1996) Proc.Natl.Acad.Sci.USA 93, 7190-7195

20. Tanemura,M., Miyagawa,S., Koyota,S., Koma,M., Matsuda,H., Tsuji,S., Shirakura,R., and Taniguchi,N. (1998) J.Biol.Chem. 273, 1642116425

21. Tanemura,M., Miyagawa,S., Ihara,Y., Mikata,S., Matsuda,H., Shirakura,R., and Taniguchi,N. (1997) Transplant.Proc. 29, 891-892

22. Tanemura,M., Miyagawa,S., Ihara,Y., Nishikawa,A., Suzuki,M., Yamamura,K., Matsuda,H., Shirakura,R., and Taniguchi,N. (1997) Transplant.Proc. 29, 895-896

23. Koma,M., Miyagawa,S., Honke,K., Ikeda,Y., Koyota,S., Miyoshi,S., Matsuda,H, Tsuji,S., Shirakura,R., and Taniguchi,N. (2000) Glycobiology 10, 745-751

24. Fukuta,K., Abe,R., Yokomatsu,T., Omae,F., Asanagi,M., and Makino,T. (2000) J. Biol.Chem. 275, 23456-23461

25. Schachter,H. (1986) Biochem.Cell.Biol. 64, 163-181.

26. Schachter,H., Narasimhan,S., Gleeson,P. and Vella,G. (1983) Can.J.Biochem.Cell.Biol. 61, 1049-1066

27. Schachter,H. (1991) Glycobiology 1, 453-461

28. Gleeson,P.A. and Schachter,H. (1983) J.Biol.Chem. 258, 6162-6173

29. Fujii,S., Nishiura,T., Nishikawa,A., Miura,R., and Taniguchi,N. (1990) J.Biol.Chem. 265, 6009-6018

30. Roth,J. (1987) Biochim.Biophys.Acta 906, 405-436

31. Berger,E.G., Mandel,T., and Schilt,U. (1981) J.Histochem.Cytochem. 29, 364-370

32. Nilsson,T., Pypaert,M., Hoe,M.H., Slusarewicz,P., Berger,E.G., and Warren,G. (1993) J.Cell Biol. 120, 5-13

33. Rabouille,C., Hui,N., Hunte,F., Kieckbusch,R., Berger,E.G., Warren,G., and Nilsson,T. (1995) J.Cell Sci. 108, 1617-1627

34. Roth,J. and Berger,E.G. (1982) J.Cell Biol. 92, 223-229

35. Ihara,Y., Senda,T., Nishikawa,A., Miyoshi,E., Yoshimura,M., Zhang,N-Z. and Taniguchi,N. (1995) Glycoconj.J. 12, 447

36. Nagai,K., Ihara,Y., Wada,Y. and Taniguchi,N. (1997) Glycobiology 7, 769-776

37. Colley,K.J. (1997) Glycobiology 7, 1-13 


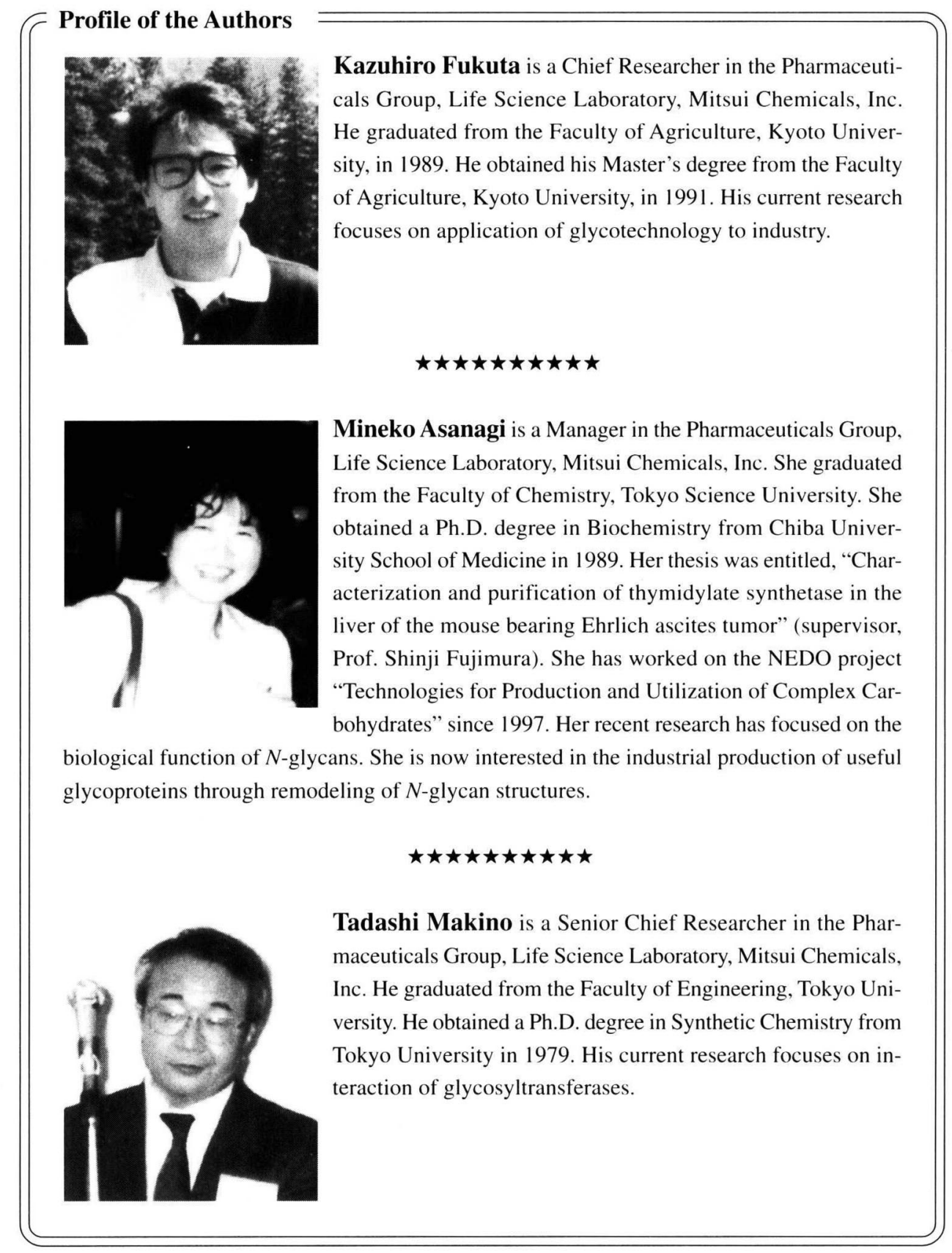

